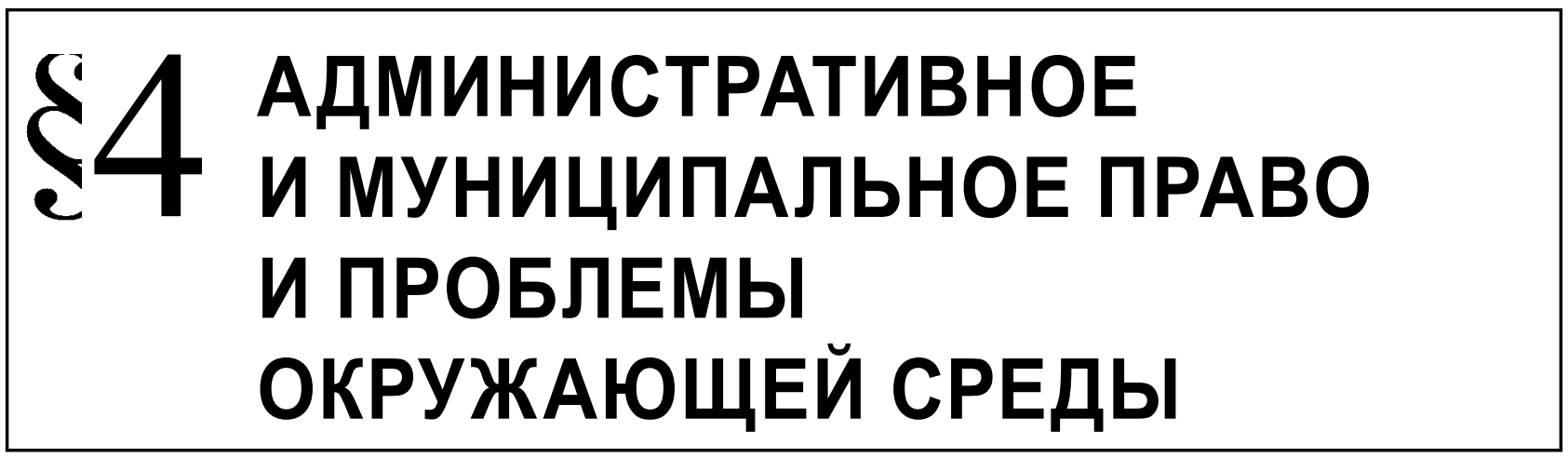

Курилова Е.В.

\title{
ЗАДАЧИ И ОСНОВНЫЕ НАПРАВЛЕНИЯ ПРОКУРОРСКОГО НАДЗОРА ЗА ИСПОЛНЕНИЕМ ЗАКОНОДАТЕЛЬСТВА ОБ АДМИНИСТРАТИВНОЙ ОТВЕТСТВЕННОСТИ В ЭКОЛОГИЧЕСКОЙ СФЕРЕ
}

Аннотация: Статья посвящена определению задач и основных направлений прокурорского надзора за исполнением законодательства об административной ответственности в экологической срере. Принимая во внимание цели Стратегии национальной безопасности Российской Федерации, утвержденной Указом Президента Российской Федерации от 12.05.2009 №537, задачи прокурорского надзора, которые корреспондируют челям и задачам, закрепленным в Кодексе Российской Федерации об административных правонарушениях, сделан вывод о том, что направление прокурорского надзора за исполнением законодательства об административной ответственности в экологической срере относится к приоритетным. В статье определяются специальные задачи, присущие прокурорскому надзору за исполнением законодательства об административной ответственности в экологической срере. В статье также определены научно и практически обоснованные основные направления деятельности органов прокуратуры по надзору за исполнением законодательства об административной ответственности в экологической срере. Методологическую основу работы составили общенаучный диалектический и частнонаучные методы познания социально-правовых явлений, осуществления и организации прокурорского надзора за исполнением законодательства об административной ответственности в экологической срере. При выборе основных направлений деятельности органов прокуратуры по надзору за исполнением законодательства об административной ответственности в экологической срере автор руководствовался состоянием прокурорского надзора за исполнением законодательства об административной ответственности и в экологической сфрере, в том числе возрастающим количеством выявляемых административных правонарушений не только прокурорами, но и контролирующими (надзорными) органами. В статье выделены основные направления деятельности органов прокуратуры по надзору за исполнением законодательства об административной ответственности $в$ экологической сфере в настоящее время и ближайшую перспективу.

Ключевые слова: прокурорский, надзор, законодательства, административной, ответственности, экологической, срере, задачи, основные, направления.

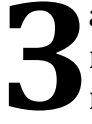
адачи любого направления деятельности органов прокуратуры и в особенности ее надзорной функции подчинены целям, для достижения которых созданы эти органы. В силу пункта 2 ст. 1 Федерального закона «0 прокуратуре Российской Федерации» ${ }^{1}$ (далее - Закон о прокуратуре)

1 О прокуратуре Российской Федерации: Федеральный за- к целям деятельности органов прокуратуры отнесены: обеспечение верховенства закона, единства и укрепления законности; защита прав и свобод человека и гражданина, охраняемых законом интересов общества и государства. Рассматриваемые

кон от 17.01.1992 № 2202-1 // С3 РФ. 1995. № 47. Ст. 4472 (с последующими изменениями). 
цели также преследуются и при осуществлении прокурорского надзора за исполнением законодательства об административной ответственности в экологической сфере.

В науке прокурорского надзора деятельность прокуратуры, отражающая ее сущность, выражающаяся в достижении отмеченных целей, определяется понятием «функция» прокуратуры (А.П. Глебов, В.П. Рябцев, А.Я. Сухарев ${ }^{2}$ и др.). При этом основной функцией прокуратуры выделяется надзор за соблюдением Конституции Российской Федерации и исполнением законов, действующих на территории Российской Федерации.

Надзорная функция прокуратуры подразделяется на отдельные, самостоятельные ее части, обозначаемые в науке прокурорского надзора термином «отрасль», которые нашли свое отражение в Законе о прокуратуре. В свою очередь, в научных кругах отрасли прокурорской надзорной деятельности условно подразделяется на подотрасли, направления, участки надзорной деятельности и т.д., в зависимости от применения критерия практической целесообразности, выражающегося в необходимости решения определенных задач, а также изучения соответствующих направлений надзорной деятельности в науке прокурорского надзора ${ }^{3}$.

Надзорная деятельность органов прокуратуры распространяется на многие правовые отношения, в том числе складывающиеся при исполнении законодательства об административной ответственности в экологической сфере, под которой нами понимается область охраны окружающей среды и природопользования, а также обеспечения экологической безопасности - триада общественных отношений, составляющая согласно сложившимся канонам в науке экологического права предмет регулирования соответствующей правовой отрасли, и в качестве предмета совместного ведения России и ее субъектов введена в пункте «д» ч. 1 ст. 72 Конституции Российской Федерации ${ }^{4}$.

\footnotetext{
2 Глебов А.П. Функции прокурорского надзора // Совершенствование прокурорского надзора в СССР. М., 1973; Российский прокурорский надзор: учебник / под ред. проф. А.Я. Сухарева. М., 2001. С.59 и др.

3 Казарина А.Х. Предмет и пределы прокурорского надзора за исполнением законов (сфера предпринимательской и иной экономической деятельности) / Ин-т повышения квалификации рук. кадров Ген. прокуратуры Рос. Федерации. M., 2005. C.25- 27,

4 См. Винокуров А.Ю. Основы государственной политики в области экологического развития Российской Федерации: руководство к действию или декларация? // Правовое обе-
}

В теории прокурорского надзора сформировалось представление о трехуровневой системе задач прокурорского надзора ${ }^{5}$, включающей:

1) общие (основные) задачи - решаемые в процессе осуществления органами прокуратуры всех направлений деятельности. К примеру, профессор Б.В. Коробейников к числу общих задач относит охрану закрепленного в Конституции Российской Федерации общественного и государственного строя, охрану гарантированных конституционных прав и охраняемых законом интересов граждан и пр. ${ }^{6}$;

2) специальные задачи - решаемые в рамках конкретных видов деятельности (направлений, участков) прокурорского надзора;

3) частные задачи - порождаемые конкретной надзорной ситуацией, носящие временный характер и зависящие от конкретных условий, вида применяемого правового средства и пр.

Именно наличие специальных и частных задач формирует разноплановый характер конкретных направлений (участков) надзорной деятельности, которые находят свое отражение в руководящих указаниях Генерального прокурора Российской Федерации с учетом поставленных государственных задач, реалий действительности и анализа состояния законности, и «не являются раз и навсегда определенными, они изменяются сообразно развитию экономических и социально-политических процессов, происходящих в государстве и обществе» ${ }^{7}$.

Таким образом, имея в качестве ориентира обозначенные законодателем цели своей деятельности, органы прокуратуры при осуществлении надзора за исполнением законодательства об административной ответственности в экологической сфере выполняют задачи, которые называются специальными ${ }^{8}$.

В соответствии со Стратегией национальной безопасности Российской Федерации, утвержден-

спечение экологической безопасности в Российской Федерации: сборник материалов научной конференции, проведенной на юридическом факультете МосГУ 25.03.2013 / отв.ред. А.Ю. Винокуров. М.: Изд-во Моск. гуманит. ун-та. 2013. С. 4.

5 Прокурорский надзор: учеб. пособие / под ред. В.Н. Григорьева. М.: Изд-во «Элит», 2007. С. 16.

6 Прокурорский надзор / под ред. Ю.Е. Винокурова. М.: Высшее образование. 2005. С. 17.

Бессарабов В.Г. Прокурорский надзор: Учебник. М.: ТК Велби, Проспект, 2007. С. 189.

8 Прокурорский надзор: Учебник / под общ.ред. Ю.Е. Винокурова. М.: Изд-во Юрайт, 2001. С. 17. 
ной Указом Президента Российской Федерации от 12.05.2009 №5379, стратегическими целями обеспечения экологической безопасности и рационального природопользования являются: сохранение окружающей природной среды и обеспечение ее защиты; ликвидация экологических последствий хозяйственной деятельности в условиях возрастающей экономической активности и глобальных изменений климата.

При этом мы, соглашаясь с мнением профессора Винокурова А.Ю., полагаем, что цели и задачи прокуратуры в рассматриваемой сфере обусловлены фактическим состоянием окружающей среды в регионах и в целом в стране, состоянием использования природных ресурсов, отражающих в немалой степени уровень исполнения экологического законодательства, поскольку неудовлетворительное состояние окружающей среды, нерациональное использование природных ресурсов, угроза экологической безопасности означает, что кем-то допускаются экологические правонарушения, не соблюдаются соответствующие нормативы качества окружающей среды, нормы и правила использования природных ресурсов (земли, полезных ископаемых, лесов, рыбных запасов и других)» ${ }^{10}$.

Прокурорский надзор за исполнением законодательства об административной ответственности в экологической сфере в данном случае направлен на обеспечение экологической безопасности как в целом страны, так и ее отдельных регионов основы основ хорошего здоровья россиян и увеличения продолжительности их жизни, на защиту экологических прав граждан и иных лиц, закрепленных в Конституции Российской Федерации ${ }^{11}$.

Данные задачи прокурорского надзора должны корреспондировать целям и задачам, закрепленным в Кодексе Российской Федерации об административных правонарушениях КоАП РФ (далее - КоАП РФ) ${ }^{12}$.

\footnotetext{
9 СЗ РФ. 2009. № 20. Ст. 2444 (с последующими изменениями).
}

10 См.: Винокуров А.Ю. О целях и задачах природоохранной деятельности российской прокуратуры // Актуальные вопросы российского права. Вып.1. М.: МосГУ, 2006 // http:// rudocs.exdat.com/docs/index-223683.html (дата обращения 05.12.2013).

11 См.: Винокуров А.Ю. О целях и задачах природоохранной деятельности российской прокуратуры // Актуальные вопросы российского права. Вып.1. М.: МосГУ, 2006 // http:// rudocs.exdat.com/docs/index-223683.html (дата обращения 05.12.2013)

12 Кодекс Российской Федерации об административных правонарушениях от 30.12.2001 № 195-Ф3 // СЗ РФ. 2001. № 1 (ч. 1). Ст. 1 (с последующими изменениями).
КоАП РФ в ст. 1.1 закрепил, что законодательство об административных правонарушениях состоит из указанного Кодекса и принимаемых в соответствии с ним законов субъектов Российской Федерации об административных правонарушениях.

В настоящее время КоАП РФ является единственным федеральным законодательным актом, устанавливающим составы административных правонарушений в экологической сфере и виды наказаний за их совершение на всей территории Российской Федерации.

В силу ст. 1.2 КоАП РФ к задачам законодательства об административных правонарушениях отнесены: защита личности, охрана прав и свобод человека и гражданина, охрана здоровья граждан, санитарно-эпидемиологического благополучия населения, ... охрана окружающей среды, ... защита законных экономических интересов физических и юридических лиц, общества и государства от административных правонарушений, а также предупреждение административных правонарушений.

В свою очередь целью административного наказания согласно ч. 1 ст. 3.1 КоАП РФ является предупреждение совершения новых правонарушений как самим правонарушителем, так и другими лицами.

Кроме того, статья 24.1 КоАП РФ определяет задачами производства по делам об административных правонарушениях: всестороннее, полное, объективное и своевременное выяснение обстоятельств каждого дела, разрешение его в соответствии с законом, обеспечение исполнения вынесенного постановления, а также выявление причин и условий, способствовавших совершению административных правонарушений.

Согласно данным официального сайта Росстата из суммы наложенных штрафов по стране за административные правонарушения в сфере экономики ${ }^{13}$ реально взыскано лишь около $7 \%{ }^{14}$.

Изучение организационно-распорядительных документов Генерального прокурора Российской Федерации позволяет выделить наиболее близкий к рассматриваемому нами направлению надзора - приказ Генерального прокуратура Российской Федерации от 07.12.2007 № 195 «Об организации прокурорского надзора за исполнением

\footnotetext{
13 Форма 1-АЭ также учитывает привлечение к административной ответственности за большинство правонарушений из Главы 8 КоАП РФ в сфере охраны окружающей среды и природопользования.

14 http://www.fedstat.ru/indicators/start.do (дата обращения 05.12.2013).
} 
законов, соблюдением прав и свобод человека и гражданина» ${ }^{15}$, в котором одним из основных направлений надзорной деятельности выделен надзор в сфере экологической безопасности.

Анализ положений указанного приказа, а также действующего законодательства позволяет в качестве задач, стоящих перед прокурорами в рассматриваемом нами направлении, определить:

- обеспечение законности правовых актов, издаваемых федеральными органами исполнительными власти, законодательными (представительными) и исполнительными органами субъектов Российской Федерации, органами местного самоуправления, органами контроля (надзора), их должностными лицами (независимо от поступления информации о нарушениях законности);

- обеспечение законности в деятельности контролирующих органов по выявлению и пресечению экологических правонарушений;

- обеспечение законности административного задержания, примененного на основании решений несудебных органов.

В то же время задачи органов прокуратуры при осуществлении надзора за законностью решений, принимаемых органами административной юрисдикции, должны вытекать из предмета этой деятельности, поэтому к специальным задачам прокурорского надзора в рассматриваемой сфере можно отнести ${ }^{16}$ обеспечение в органах административной юрисдикции:

- законности и обоснованности привлечения к административной ответственности физических, должностных и юридических лиц за экологические правонарушения, предусмотренные КоАП РФ и законами субъектов Российской Федерации об административных правонарушениях, начиная с момента составления протоколов об административных правонарушениях, инициирования и проведения административного расследования;

- $\quad$ законности применения мер обеспечения производства по делам об административных правонарушениях в экологической сфере;

- $\quad$ законности при принятии мер по привлечению к административной ответственности

15 Законность. 2008. № 3.

16 См.: Викторов И.С. Прокурорский надзор за исполнением законодательства об административной ответственности: учебное пособие / под ред. Ю.Е. Винокурова. - М.: Издательство «Экзамен», 2006 г. С.53. физических, должностных и юридических лиц за совершение экологических правонарушений; законности вынесения решений при рассмотрении дел об административных правонарушениях, а также решений, принимаемых в порядке пересмотра таких решений;

- законности и своевременности обращения к исполнению вынесенных постановлений по делам об административных правонарушениях в экологической сфере, в том числе постановки вопроса перед службой судебных приставов-исполнителей о принудительном исполнении вынесенных по делу постановлений;

- законности внесенных в соответствующие организации или должностным лицам представлений об устранении причин и условий, способствовавших совершению административного правонарушения в экологической сфере;

логических правонарушений (профилактика административных правонарушений).

Анализ деятельности территориальных и природоохранных прокуратур при привлечении к административной ответственности в экологической сфере позволяет выявить следующую особенность: несмотря на большое количество контрольно-надзорных органов в экологической сфере, органы прокуратуры выявляют значительное количество экологических правонарушений. Согласно данным статистического отчета о работе прокурора за период с 2011 по 2012 г. по форме «ОН» в 2012 году по постановлению (заявлению в арбитражный суд) прокурора к административной ответственности привлечено: 36,91\% (прирост +13,55\% к 2011 г.) лиц, нарушивших нормы законодательства об отходах производства и потребления от числе привлеченных к ответственности за экологические правонарушения; $26,8 \%$ (прирост $+1,77 \%$ ) - об охране вод и атмосферного воздуха; $13,03 \%$ - о лесопользовании; 7,45 \% - об охране земли, почв; 4,93 \% - об охране и использовании животного мира; 1,69 \% об охране и добыче водных биоресурсов.

Как отмечается в научных исследованиях, на начало 2013 года в России накоплено уже более 80 млрд. тонн отходов, из которых утилизируется не более $30 \%$, остальные размещаются на свалках, полигонах, большинство из которых исчерпали свой ресурс и являются реальной угрозой экологической безопасности страны. Шестая часть территории страны, где проживает более 60 млн. человек, является неблагополучной. В 40 субъектах Российской Федерации более 54 процентов городского 
населения находится под воздействием высокого и очень высокого загрязнения атмосферного воздуха, что связано в первую очередь, с ростом количества автотранспорта в городах. Объем сточных вод, сбрасываемых в поверхностные водные объекты без очистки или недостаточно очищенных, остается высоким. Свыше 40\% поверхностных источников питьевого водоснабжения и 7\% подземных не соответствуют санитарным правилам и нормам. Проблема лесных пожаров в последние годы приобрела общегосударственный масштаб. Практически во всех регионах сохраняется тенденция к ухудшению состояния почв и земель ${ }^{17}$.

Материалы прокурорских проверок свидетельствуют о массовости и широкой распространенности правонарушений в области охраны окружающей среды и природопользования, обеспечения экологической безопасности. Докладные записки прокуроров субъектов Российской Федерации, специализированных прокуратур, в частности Волжской межрегиональной природоохранной прокуратуры, свидетельствуют о распространенном характере нарушений законодательства об административной ответственности в экологической сфере. Зачастую прокурорами выявляются факты привлечения лиц к административной ответственности за совершение экологических правонарушений с нарушениями требований административного законодательства (Астраханская, Вологодская, Ивановская, Нижегородская, Рязанская, Саратовская, Ульяновская области, Республика Татарстан).

Данные факторы, согласно «теории приоритетов организации и деятельности органов прокуратуры», разработанной Т.А. Ашурбековым ${ }^{18}$, позволяют выделить направление прокурорского надзора за исполнением законодательства об администра-

17 См. Лихачева Е.Ю. Прокурорский надзор в сфере экологической безопасности // Правовое обеспечение экологической безопасности в Российской Федерации: сборник материалов научной конференции, проведенной на юридическом факультете МосГУ 25.03.2013 / отв. ред. А.Ю. Винокуров. М.: Изд-во Моск. гуманит. ун-та. 2013. С. 16-20; Ступаченко Е.В. О некоторых вопросах деятельности прокуроров по обеспечению законности сфере в экологической безопасности // Правовое обеспечение экологической безопасности в Российской Федерации: сборник материалов научной конференции, проведенной на юридическом факультете МосГУ 25.03.2013 / отв. ред. А.Ю. Винокуров. - М.: Изд-во Моск. гуманит. ун-та. 2013. С. 44-45.

18 Ашурбеков Т.А. Правовые и организационные основы надзорной и иной функциональной деятельности прокуратуры в сфере национальной безопасности: дис. ... д-ра юрид. наук. С. 312-313. тивной ответственности в экологической сфере, определив его в качестве приоритетного.

Задачи органов прокуратуры при осуществлении надзора за исполнением законодательства об административной ответственности в экологической сфере, несомненно, связаны с основными направлениями деятельности органов прокуратуры по надзору за исполнением указанного законодательства, которые, в свою очередь, и обеспечивают решение указанных выше задач.

При выборе основных направлений деятельности органов прокуратуры по надзору за исполнением законодательства об административной ответственности в экологической сфере мы руководствовались состоянием прокурорского надзора за исполнением законодательства об административной ответственности и в экологической сфере, в том числе возрастающим количеством выявляемых административных правонарушений не только прокурорами, но и контролирующими (надзорными) органами.

В качестве основных направлений деятельности органов прокуратуры по надзору за исполнением законодательства об административной ответственности в экологической сфере в настоящее время и ближайшую перспективу выделим следующие:

- $\quad$ надзор за исполнением законодательства об административной ответственности в экологической сфере федеральными органами исполнительной власти, их территориальными органами и структурными подразделениями, органами исполнительной власти субъектов Российской Федерации, их структурными подразделениями, органами местного самоуправления, а также их должностными лицами, уполномоченными применять законодательство об административной ответственности: составлять протоколы об административных правонарушениях в экологической сфере, инициировать и проводить административное расследование, применять меры обеспечения производства по делам об административных правонарушениях, рассматривать дела об административных правонарушениях, пересматривать постановления и решения по этим делам (за исключением дел, находящихся в производстве суда), а также обращать и приводить в исполнение постановления по делам об административных правонарушениях в сфере охраны окружающей среды, природопользования, обеспечения экологической безопасно- 
сти; осуществлять профилактику административных правонарушений;

- $\quad$ надзор за соответствием законам правовых актов, издаваемых перечисленными выше органами, должностными лицами (при выявлении нарушений принимать меры, направленные на пересмотр незаконных решений по делам об административных правонарушениях в экологической сфере; недопущение в последующем подобных нарушений);

- $\quad$ надзор за исполнением законов органами и должностными лицами (за исключением судов), участвующими в реализации мер административного принуждения (при этом решительно пресекать факты незаконного применения к гражданам административного задержания, активно использовать предоставленное ст. 22 Закона о прокуратуре право освобождать своим постановлением лиц, не- обоснованно подвергнутых административному задержанию на основании решений несудебных органов) и исполнении отдельных видов административных наказаний на основании главы 32 КоАП РФ (особое внимание необходимо уделять судебным приставам-исполнителям при исполнении назначенного наказания в виде штрафа в связи с крайне низким процентом взыскания, в результате чего административное наказание не достигает своей цели).

- $\quad$ соблюдение прав и свобод человека и гражданина, должностных и юридических лиц, вовлеченных в сферу производства по делу об административном правонарушении.

Данные направления способствуют реализации государственной политики в области защиты прав и свобод человека и гражданина в Российской Федерации в экологической сфере.

\section{Библиография:}

1. http://www.fedstat.ru/indicators/start.do (дата обращения 05.12.2013)

2. Ашурбеков Т.А. Правовые и организационные основы надзорной и иной функциональной деятельности прокуратуры в сфере национальной безопасности: дис. ... д-ра юрид. наук. С. 312-313.

3. Бессарабов В.Г. Прокурорский надзор: Учебник. М.: ТК Велби, Проспект, 2007. С. 189.

4. Викторов И.С. Прокурорский надзор за исполнением законодательства об административной ответственности: учебное пособие / под ред. Ю.Е. Винокурова. - М.: Издательство «Экзамен», 2006 г. С.53.

5. Винокуров А.Ю. О целях и задачах природоохранной деятельности российской прокуратуры // Актуальные вопросы российского права. Вып.1. М.: МосГУ, 2006 // http://rudocs.exdat.com/docs/ index-223683.html (дата обращения-05.12.2013).

6. Винокуров А.Ю. Основы государственной политики в области экологического развития Российской Федерации: руководство к действию или декларация? // Правовое обеспечение экологической безопасности в Российской Федерации: сборник материалов научной конференции, проведенной на юридическом факультете МосГУ 25.03.2013 / отв.ред. А.Ю. Винокуров. М.: Изд-во Моск. гуманит. унта. 2013. С. 4.

7. Глебов А.П. Функции прокурорского надзора // Совершенствование прокурорского надзора в СССР. М., 1973; Российский прокурорский надзор: учебник / под ред. проф. А.Я. Сухарева. М., 2001. С.59 и др.

8. Законность. 2008. № 3.

9. Казарина А.Х. Предмет и пределы прокурорского надзора за исполнением законов (сфера предпринимательской и иной экономической деятельности) / Ин-т повышения квалификации рук. кадров Ген. прокуратуры Рос. Федерации. М., 2005. С.25- 27.

10. Кодекс Российской Федерации об административных правонарушениях от 30.12.2001 № 195-Ф3 // СЗ РФ. 2001. № 1 (ч. 1). Ст. 1 (с последующими изменениями).

11. Лихачева Е.Ю. Прокурорский надзор в сфере экологической безопасности // Правовое обеспечение экологической безопасности в Российской Федерации: сборник материалов научной конференции, проведенной на юридическом факультете МосГУ 25.03.2013 / отв. ред. А.Ю. Винокуров. - М.: Изд-во Моск. гуманит. ун-та. 2013. С. 16-20.

12. Ступаченко Е.В. О некоторых вопросах деятельности прокуроров по обеспечению законности сфере в экологической безопасности // Правовое обеспечение экологической безопасности в Российской Федерации: сборник материалов научной конференции, проведенной на юридическом факультете МосГУ 25.03.2013 / отв. ред. А.Ю. Винокуров. - М.: Изд-во Моск. гуманит. ун-та. 2013. С. 44-45. 
13. О прокуратуре Российской Федерации: Федеральный закон от 17.01.1992 № 2202-1 // СЗ РФ. 1995. № 47. Ст. 4472 (с последующими изменениями).

14. Прокурорский надзор / под ред. Ю.Е. Винокурова. М.: Высшее образование. 2005. С. 17.

15. Прокурорский надзор: учеб. пособие / под ред. В.Н. Григорьева. М.: Изд-во «Элит», 2007. С. 16.

16. Прокурорский надзор: Учебник / под общ.ред. Ю.Е. Винокурова. М.: Изд-во Юрайт, 2001. С. 17.

17. СЗ РФ. 2009. № 20. Ст. 2444 (с последующими изменениями).

\section{References (transliterated):}

1. $\quad$ http://www.fedstat.ru/indicators/start.do (data obrashcheniya 05.12.2013)

2. AshurbekovT.A. Pravovye i organizatsionnye osnovy nadzornoi i inoi funktsional'noi deyatel'nosti prokuratury v sfere natsional'noi bezopasnosti: dis. ... d-ra yurid. nauk. S. 312-313.

3. Bessarabov V.G. Prokurorskii nadzor: Uchebnik. M.: TK Velbi, Prospekt, 2007. S. 189.

4. Viktorov I.S. Prokurorskii nadzor za ispolneniem zakonodatel'stva ob administrativnoi otvetstvennosti: uchebnoe posobie / pod red. Yu.E. Vinokurova. — M.: Izdatel'stvo «Ekzamen», 2006 g. S.53.

5. Vinokurov A.Yu. O tselyakh i zadachakh prirodookhrannoi deyatel'nosti rossiiskoi prokuratury // Aktual'nye voprosy rossiiskogo prava. Vyp.1. M.: MosGU, 2006 // http://rudocs.exdat.com/docs/index-223683.html (data obrashcheniya-05.12.2013).

6. Vinokurov A.Yu. Osnovy gosudarstvennoi politiki v oblasti ekologicheskogo razvitiya Rossiiskoi Federatsii: rukovodstvo k deistviyu ili deklaratsiya? // Pravovoe obespechenie ekologicheskoi bezopasnosti v Rossiiskoi Federatsii: sbornik materialov nauchnoi konferentsii, provedennoi na yuridicheskom fakul'tete MosGU 25.03.2013 / otv.red. A.Yu. Vinokurov. M.: Izd-vo Mosk. gumanit. un-ta. 2013. S. 4.

7. Glebov A.P. Funktsii prokurorskogo nadzora // Sovershenstvovanie prokurorskogo nadzora v SSSR. M., 1973; Rossiiskii prokurorskii nadzor: uchebnik / pod red. prof. A.Ya. Sukhareva. M., 2001. S.59 i dr.

8. Zakonnost'. 2008. № 3.

9. Kazarina A.Kh. Predmet i predely prokurorskogo nadzora za ispolneniem zakonov (sfera predprinimatel'skoi i inoi ekonomicheskoi deyatel'nosti) / In-t povysheniya kvalifikatsii ruk. kadrov Gen. prokuratury Ros. Federatsii. M., 2005. S.25- 27.

10. Kodeks Rossiiskoi Federatsii ob administrativnykh pravonarusheniyakh ot 30.12.2001 № 195-FZ // SZ RF. 2001. № 1 (ch. 1). St. 1 (s posleduyushchimi izmeneniyami).

11. Likhacheva E.Yu. Prokurorskii nadzor v sfere ekologicheskoi bezopasnosti // Pravovoe obespechenie ekologicheskoi bezopasnosti v Rossiiskoi Federatsii: sbornik materialov nauchnoi konferentsii, provedennoi na yuridicheskom fakul'tete MosGU 25.03.2013 / otv. red. A.Yu. Vinokurov. — M.: Izd-vo Mosk. gumanit. un-ta. 2013. S. $16-20$

12. Stupachenko E.V. O nekotorykh voprosakh deyatel'nosti prokurorov po obespecheniyu zakonnosti sfere $\mathrm{v}$ ekologicheskoi bezopasnosti // Pravovoe obespechenie ekologicheskoi bezopasnosti v Rossiiskoi Federatsii: sbornik materialov nauchnoi konferentsii, provedennoi na yuridicheskom fakul'tete MosGU 25.03.2013 / otv. red. A.Yu. Vinokurov. - M.: Izd-vo Mosk. gumanit. un-ta. 2013. S. 44-45.

13. O prokurature Rossiiskoi Federatsii: Federal'nyi zakon ot 17.01.1992 № 2202-1 // SZ RF. 1995. № 47. St. 4472 (s posleduyushchimi izmeneniyami).

14. Prokurorskii nadzor / pod red. Yu.E. Vinokurova. M.: Vysshee obrazovanie. 2005. S. 17.

15. Prokurorskii nadzor: ucheb. posobie / pod red. V.N. Grigor'eva. M.: Izd-vo «Elit», 2007. S. 16.

16. Prokurorskii nadzor: Uchebnik / pod obshch.red. Yu.E. Vinokurova. M.: Izd-vo Yurait, 2001. S. 17.

17. SZ RF. 2009. № 20. St. 2444 (s posleduyushchimi izmeneniyami). 